\title{
AN ADDITION OF SOURDOUGH AND WHEY PROTEINS AFFECTS THE NUTRITIONAL QUALITY OF WHOLEMEAL WHEAT BREAD
}

\author{
Aneta Kopeć ${ }^{1 凶}$, Barbara Borczak ${ }^{1}$, Mirosław Pysz ${ }^{1}$, Elżbieta Sikoraํ․ Marek Sikora², \\ Duska Curic ${ }^{3}$, Dubravka Novotni ${ }^{3}$ \\ ${ }^{1}$ Department of Human Nutrition, University of Agriculture in Krakow \\ Balicka 122, 30-149 Krakow, Poland \\ 2Department of Carbohydrate Technology, University of Agriculture in Krakow \\ Balicka 122, 30-149 Krakow, Poland \\ ${ }^{3}$ Faculty of Food Technology and Biotechnology, University of Zagreb \\ Pierottijeva 6, HR-10000 Zagreb, Croatia
}

\begin{abstract}
Background. Bread can be a good source of nutrients as well as non-nutrient compounds. This study was designed to assess the effect of adding of sourdough and whey proteins to wholemeal (WM) bread produced by bake-off technology on chemical composition and bioavailability of proteins, calcium, phosphorus, magnesium and iron content in Wistar rats.

Material and methods. Wholemeal breads were baked with using conventional or bake off technology. In breads chemical composition, selected minerals content, amino acid composition were measured. Five week-old Wistar rats $(n=30$, male), were randomly divided into five groups and fed with modified AIN-93G diets containing experimental breads. In animal study the nutritional value of breads' proteins and concentration of selected minerals in serum, liver and femoral bone, were measured.

Results. The body weight gain, biological value (BV) and net protein utilization (NPU) were significantly higher in rats fed with partially baked frozen wholemeal (PBF WM) bread with sourdough and whey proteins. The level of magnesium was significantly lower in serum of animals fed with the diet containing PBF WM bread with sourdough and whey proteins in comparison to rodents fed with conventional WM bread with sourdough. The content of iron was significantly higher in liver of rats fed with PBF WM with sourdough bread in comparison to the groups fed with conventional WM and conventional WM with sourdough breads. Conclusions. Sourdough addition can be recommended in a production of whole wheat partially baked frozen bread but its use is further more beneficial if it is fermented with whey proteins.
\end{abstract}

Key words: minerals, partially baked frozen, sourdough, whey proteins, wholemeal bread, rats

\section{ABBREVIATIONS}

$\mathrm{BV}$ - biological value, CS - chemical score, EAA - exogenic amino acid index, NPU - net protein utilization, PBF - partially baked frozen bread, PDCAAS - protein digestibility corrected amino acids score, PER - protein efficiency ratio, WM - whole meal, TD - total digestibility of protein.

\section{INTRODUCTION}

Cereal products, especially wholemeal products and unprocessed grains, should be consumed at least 5 times per day according to dietary guidelines in $\mathrm{Eu}-$ ropean countries [Gawęcki 2010, Winiarska-Mieczan and Kwiecien 2011]. Bread is an excellent source of nutrients as well as non-nutrient compounds. Higher

『akopec@ar.krakow.pl 
consumption of bread baked from wholemeal flour will increase consumption of dietary fiber in an average daily diet. World Health Organization - WHO recommends that intake of fiber should be between 25-40 g per day [WHO/FAO 2003] whereas in different populations it is usually too low [Gawęcki 2010, Pysz-Izdebska et al. 2010]. It has been well reported that diets rich in food products being a good source of dietary fiber may reduce the risk of non communicable diseases (obesity, cardiovascular diseases, colon cancer) [Górecka et al. 2010, Poutanen et al. 2009].

Dietary fiber apart from health-related functions plays an important role in creating an appropriate texture of dough and a final product, i.e. bread. The main reason for these properties is the natural ability to bind water [Poutanen et al. 2009, Rossell et al. 2009].

An addition of sourdough or other natural compounds (whey proteins) to wholemeal dough is an important factor in improving texture and flavor and increasing content of bioactive and nutritional compounds [Rossell et al. 2009, Katina et al. 2005]. Technology of baking also affects the quality of wholemeal breads. Rosell et al. [2009] reported that wholemeal bread prepared by bake-off technology was softer and its hardness was not influenced by storage conditions. It has been also reported that addition of sourdough and dietary fiber (inulin and oat fibers) affects the nutritional value of wheat breads prepared by bake-off technology [Kopeć et al. 2011].
This study was designed to assess the effect of partially baking and freezing technology as well as an addition of sourdough and whey proteins to wholemeal bread on the biological value of proteins and selected mineral concentration in experimental rats. Such approach (combination of bake-off technology and an addition of sourdough and whey proteins) is innovative and was not till now investigated from the nutritional point of view.

\section{MATERIAL AND METHODS}

\section{Bread preparation}

The wholemeal wheat breads were prepared by an adaptation of model recipes from Novotni et al. [2011] (Table 1). The wholemeal wheat flour (Farina, Zagreb, Croatia), salt (Janikosoda S.A., Janikowo, Poland), yeast (SAF - Instant red - Lesaffre Group, Strasbourg, France, Freshbake improver developed for the Freshbake project, freshly fermented sourdough fermented wheat flour by heterofermentative culture Lactobacillus fermentum Pallazzo PL1 (Piemonte, Kirchzarten, Germany) and whey proteins (Meggle, Wasserburg am Inn, Germany) were used. All breads were prepared with an addition of the 1\% Freshbake improver described in our previous paper [Kopeć et al. 2011]. Breads with sourdough were prepared with an addition of $15 \%$ fresh sourdough, prepared with or without adding whey proteins.

Table 1. Share of the dough ingredients of wheat breads with sourdough and whey proteins

\begin{tabular}{|c|c|c|c|c|c|}
\hline $\begin{array}{l}\text { Ingredient } \\
\quad \% *\end{array}$ & Conventional WM & $\begin{array}{c}\text { Conventional WM } \\
\text { sourdough }\end{array}$ & $\begin{array}{l}\text { PBF WM } \\
\text { improved }\end{array}$ & $\begin{array}{l}\text { PBF WM } \\
\text { sourdough }\end{array}$ & $\begin{array}{c}\text { PBF WM } \\
\text { sourdough, whey } \\
\text { proteins }\end{array}$ \\
\hline Wheat flour & 100 & 100 & 100 & 100 & 100 \\
\hline Water & 64 & 64 & 64 & 64 & 64 \\
\hline Yeast & 3 & 3 & 3 & 3 & 3 \\
\hline Salt & 1.5 & 1.5 & 1.5 & 1.5 & 1.5 \\
\hline Gluten flour & 1 & 1 & 1 & 1 & 1 \\
\hline Fresh sourdough & - & 15 & - & 15 & 15 \\
\hline Whey proteins & & & & & 4.75 \\
\hline Improver & 1 & 1 & 1 & 1 & 1 \\
\hline
\end{tabular}

*On the flour basis. 
Kopeć A., Borczak B., Pysz M., Sikora E., Sikora M., Curic D., Novotni D., 2014. An addition of sourdough and whey proteins affects the nutritional quality of wholemeal wheat bread. Acta Sci. Pol., Technol. Aliment. 13(1), 43-54.

Sourdough without whey proteins was prepared by mixing meal flour $(\mathrm{g})$, starter cultures (g) with tap water $(\mathrm{g})$ and proofed at $30^{\circ} \mathrm{C}$ until the mixture reached the $\mathrm{pH}$ value of $4.0(\sim 18 \mathrm{~h})$. Sourdough with whey proteins was prepared identically as mentioned above, however it contained whey proteins additionally.

Bread dough was prepared by mixing all ingredients in a spiral mixer DIOSNA SP-12 (Dierks $\&$ Soehne, GmbH, Osnabrueck, Germany) for 9 min. The conventional breads were proofed at $30^{\circ} \mathrm{C}$ at $95 \%$ RH until the dough volume expanded 4.8 times, and the PBF breads until the dough volume expanded 3.6 times. Conventional baking was carried out at $230^{\circ} \mathrm{C}$, for $20 \mathrm{~min}$ in an electric oven (MIWE, Arnstein, Germany). Other portions of breads was partially baked at $190-200^{\circ} \mathrm{C}$ for $30 \mathrm{~s}$, then at $180-170^{\circ} \mathrm{C}$ for $16 \mathrm{~min}$ and $30 \mathrm{~s}$, frozen in a blast freezer $\left(-30^{\circ} \mathrm{C}, 30 \mathrm{~min}\right)$ and stored in a freezer $\left(-18^{\circ} \mathrm{C}\right)$ in airtight containers, for at least fourteen days. After storage, PBF breads were defrosted for $10 \mathrm{~min}$ at room temperature and rebaked at $210-220^{\circ} \mathrm{C}$, for $8 \mathrm{~min}$.

\section{Chemical composition of breads}

Total proteins (950.36), raw fat, (935.38) total dietary fiber (991.43) and ash (930.05) in experimental breads were measured according to AOAC methods [AOAC 2006].

\section{Measurements of minerals in experimental breads}

Samples for the determination of ash components were prepared according to EN 13804 Standard [EN-13804 2002]. Mineralization was accomplished using the dry-ashing method, modified acc. to the AOAC
985.01 method [AOAC 2006] as reported previously [Kopeć et al. 2011]. The level of $\mathrm{Ca}, \mathrm{P}, \mathrm{Mg}$ and Fe was estimated with the inductively coupled plasma atomic emission spectrometer JY 238 Ultratrace (Jobin-Yvon, France) according to the EN 14084 Standard [EN-14084 2003].

\section{Amino acid composition and nutritional value of breads' proteins}

Amino acids were determined quantitatively and qualitatively by the use of the AAA 400 (INGOS s.r.o., Prague, Czech Republic) [Davidson 2003]. Chemical indices (CS and EAA) of protein quality and Protein digestibility corrected amino acids score (PDCAAS) were calculated according to the FAO/WHO guidelines [FAO/WHO 2007].

\section{Experimental diets and animal procedures}

Five week-old Wistar rats ( $n=30$, male) were purchased from Animal Husbandry in Warsaw, Poland. All experimental procedures were approved by I Regional Ethics Committee on Animal Experimentation in Krakow (Poland). Before their division into experimental groups the animals were acclimatized for 7 days on standard laboratory chow. After this period rats were randomly divided into five groups and fed with modified AIN-93G diets [Reeves 1993]. The rodents were housed separately in stainless steel metabolic cages at $25^{\circ} \mathrm{C}$ and $12 / 12-$ light/dark cycle. Breads before addition to the diets were dried and grinded. The diets aimed to deliver $1 \mathrm{~g}$ of proteins per day, according to $\mathrm{FAO} / \mathrm{WHO}$ [FAO/WHO 2007], and all of them were isocaloric. Experimental diets are listed in Table 2. Free access to water was assured, the diets'

Table 2. Composition of experimental diets

\begin{tabular}{lccccc}
\hline $\begin{array}{c}\text { Ingredient } \\
\mathrm{g} \cdot \mathrm{kg}^{-1}\end{array}$ & $\begin{array}{c}\text { Conventional } \\
\text { WM }\end{array}$ & $\begin{array}{c}\text { Conven- } \\
\text { tional WM, } \\
\text { sourdough }\end{array}$ & PBF WM & $\begin{array}{c}\text { PBF WM } \\
\text { sourdough }\end{array}$ & $\begin{array}{c}\text { PBF WM, } \\
\text { sourdough, } \\
\text { whey proteins }\end{array}$ \\
\hline Bread & 771.6 & 715.8 & 781.9 & 703.2 & 692.0 \\
Corn starch & 133.4 & 189.2 & 123.1 & 201.8 & 213 \\
Canola oil & 50 & 50 & 50 & 50 & 50 \\
Vitamin mix & 10 & 10 & 10 & 10 & 10 \\
Mineral mix & 35 & 35 & 35 & 35 & 35 \\
\hline
\end{tabular}


consumption, as well as the body weight gain of animals were recorded during the whole experiment.

Urine and faeces were collected between the $5-10^{\text {th }}$ day of the experiment to determinate proteins indices (BV, TD, PER and NPU).

At the end of the experiment (day $29^{\text {th }}$ ), fasted rats were anaesthetized with thiopental (Biocheme $\mathrm{GmbH}$, Austria). Blood was collected and the serum was separated by centrifugation $(1500 \times \mathrm{g}, 15 \mathrm{~min})$. Livers and femoral bones were washed in $0.9 \%$ sodium chloride and were dried and weighted.

\section{Analyses of serum, livers and femoral bones}

The content of $\mathrm{Ca}, \mathrm{Mg}, \mathrm{Fe}$ and $\mathrm{P}$ in serum were determined by the use of commercial kits - Roche cat.-no 20763128322, cat.-no 20737593, cat.-no 03183696122, and cat.-no 0318379322, respectively. The levels of $\mathrm{Ca}, \mathrm{P}, \mathrm{Mg}$ and $\mathrm{Fe}$ in liver and femoral bones of the rats were measured by using the inductively coupled plasma atomic emission spectrometer JY 238 Ultratrace (Jobin-Yvon, France) as was previously reported [Kopeć et al. 2011].

\section{Statistical analysis}

The data was presented as mean $\pm \mathrm{SD}$. One-way analysis of variance (Statistica v. 6.1, StatSoft, Tulsa, OK, USA) was applied for testing the differences between experimental treatments. The Duncan test was used for the identification of the statistically significant differences at a level of $\mathrm{P}<0.05$.

\section{RESULTS}

\section{Chemical composition of experimental breads}

Chemical composition of breads is shown in Table 3. The content of proteins, total carbohydrates, and ash did not significantly differ among the various types of breads. The concentration of fat was significantly lower in PBF WM with sourdough in comparison to conventional WM and PBF WM breads $(\mathrm{P}<0.05)$. The level of total dietary fiber was significantly higher in conventional WM bread, and PBF WM bread in comparison to the rest of experimental breads (Table 3). The higher concentration of calcium was in breads PBF WM enriched with sourdough and whey proteins, and $\mathrm{PBF}$ wholemeal with sourdough in comparison to the rest of experimental breads. The significantly $(\mathrm{P}<0.05)$ higher level of phosphorus was measured in PBF WM bread with sourdough and whey proteins in comparison to conventional WM bread and conventional WM sourdough bread. Also magnesium and iron concentrations were affected by the addition of sourdough and whey proteins to PBF WM bread in comparison to the rest of experimental breads (Table 3).

\section{Nutritional value of experimental breads' proteins}

In all experimental breads the limited essential amino acid was lysine. The Chemical Score (CS) of proteins of PBF WM breads with sourdough and whey proteins was significantly higher as compared to the rest of experimental breads (Table 3). Proteins of conventional breads WM with sourdough and PBF WM with sourdough, had significantly lower CS compared with conventional WM bread, PBF WM, and PBF WM sourdough, whey proteins breads. Protein digestibility corrected amino acids score - PDCAAS was significantly higher in proteins of PBF WM with sourdough and whey proteins bread compared to the rest of experimental breads. EAA index was significantly higher in proteins of PBF WM bread with sourdough and whey proteins compared with this index of conventional WM, conventional WM with sourdough, and PBF WM with sourdough breads.

\section{Body weight gain and nutritional proteins' parameters}

Body weight gain was significantly higher in rats fed with conventional WM bread and PBF WM with sourdough and whey proteins bread in comparison to the rest of experimental groups. Biological value $-\mathrm{BV}$ and NPU of proteins were significantly higher in groups of rodents fed with the diet with PBF WM bread with sourdough enriched with whey proteins. There was no effect on total digestibility of proteins (TD) in all experimental groups of animals (Table 4). Protein efficiency ratio - PER was significantly higher in group of rodents fed with the diet containing PBF WM bread with sourdough and whey proteins in comparison to groups of animals fed diets enriched with PBF WM, and PBF WM with sourdough breads (Table 4). 
Kopeć A., Borczak B., Pysz M., Sikora E., Sikora M., Curic D., Novotni D., 2014. An addition of sourdough and whey proteins affects the nutritional quality of wholemeal wheat bread. Acta Sci. Pol., Technol. Aliment. 13(1), 43-54.

Table 3. Chemical composition and quality of proteins of experimental breads

\begin{tabular}{|c|c|c|c|c|c|}
\hline Indicator & $\begin{array}{c}\text { Conventional } \\
\text { WM }\end{array}$ & $\begin{array}{l}\text { Conventional } \\
\text { WM sourdough }\end{array}$ & PBF WM & $\begin{array}{l}\text { PBF WM } \\
\text { sourdough }\end{array}$ & $\begin{array}{c}\text { PBF WM, } \\
\text { sourdough, } \\
\text { whey proteins }\end{array}$ \\
\hline \multicolumn{6}{|c|}{ Chemical composition, $\mathrm{g} \cdot 100^{-1} \mathrm{~g} \mathrm{~d} . \mathrm{m}$. } \\
\hline Protein & $15.87 \pm 0.57^{\mathrm{a}}$ & $17.08 \pm 0.83^{\mathrm{a}}$ & $15.89 \pm 0.21^{\mathrm{a}}$ & $16.81 \pm 0.05^{\mathrm{a}}$ & $16.92 \pm 0.12^{\mathrm{a}}$ \\
\hline Fat & $2.41 \pm 0.09^{\mathrm{a}}$ & $2.38 \pm 0.02^{\mathrm{abc}}$ & $2.43 \pm 0.14^{\mathrm{ab}}$ & $2.17 \pm 0.01^{\mathrm{c}}$ & $2.20 \pm 0.03^{\mathrm{abc}}$ \\
\hline Carbohydrates total & $69.05 \pm 0.01^{\mathrm{a}}$ & $67.87 \pm 1.03^{\mathrm{a}}$ & $68.09 \pm 0.05^{\mathrm{a}}$ & $69.89 \pm 0.05^{\mathrm{a}}$ & $69.77 \pm 0.36^{\mathrm{a}}$ \\
\hline Total dietary fiber & $13.04 \pm 0.14^{\mathrm{b}}$ & $12.13 \pm 0.03^{\mathrm{d}}$ & $13.75 \pm 0.03^{\mathrm{a}}$ & $12.49 \pm 0.07^{\mathrm{c}}$ & $11.16 \pm 0.10^{\mathrm{d}}$ \\
\hline Insoluble fiber & $10.78 \pm 0.02^{\mathrm{b}}$ & $9.62 \pm 0.05^{\mathrm{d}}$ & $11.15 \pm 0.16^{\mathrm{a}}$ & $10.10 \pm 0.01^{\mathrm{c}}$ & $8.49 \pm 0.05^{\mathrm{e}}$ \\
\hline Soluble fiber & $2.26 \pm 0.13^{\mathrm{c}}$ & $2.51 \pm 0.02^{\mathrm{ab}}$ & $2.60 \pm 0.18^{\mathrm{ab}}$ & $2.39 \pm 0.08^{c}$ & $2.67 \pm 0.07^{\mathrm{a}}$ \\
\hline Ash & $2.99 \pm 0.39^{\mathrm{a}}$ & $3.11 \pm 0.13^{\mathrm{a}}$ & $3.26 \pm 0.05^{\mathrm{a}}$ & $3.09 \pm 0.13^{\mathrm{a}}$ & $3.33 \pm 0.03^{\mathrm{a}}$ \\
\hline \multicolumn{6}{|c|}{ Minerals, $\mathrm{mg} \cdot 100 \mathrm{~g}^{-1} \mathrm{~d} . \mathrm{m}$. } \\
\hline Calcium & $36.99 \pm 0.17^{\mathrm{a}}$ & $38.66 \pm 0.58^{b}$ & $38.81 \pm 0.68^{b}$ & $40.78 \pm 1.48^{b}$ & $48.59 \pm 0.52^{\mathrm{c}}$ \\
\hline Phosphorus & $295.36 \pm 0.20^{\mathrm{d}}$ & $317.92 \pm 5.9^{\mathrm{a}}$ & $322.08 \pm 3.21^{\mathrm{ab}}$ & $327.29 \pm 5.12^{\mathrm{abc}}$ & $330.22 \pm 5.23^{\mathrm{bc}}$ \\
\hline Magnesium & $79.96 \pm 0.007^{\mathrm{c}}$ & $86.82 \pm 0.98^{\mathrm{a}}$ & $87.40 \pm 0.11^{\mathrm{a}}$ & $87.88 \pm 2.69^{\mathrm{a}}$ & $93.27 \pm 1.67^{\mathrm{b}}$ \\
\hline Iron & $4.10 \pm 0.13^{\mathrm{a}}$ & $4.07 \pm 0.049^{\mathrm{a}}$ & $4.38 \pm 0.09^{\mathrm{a}}$ & $4.26 \pm 0.21^{\mathrm{a}}$ & $5.11 \pm 0.12^{\mathrm{b}}$ \\
\hline \multicolumn{6}{|l|}{ Quality of protein, \% } \\
\hline $\mathrm{CS}$ & $45.1 \pm 1.2^{\mathrm{b}}$ & $41.2 \pm 1.5^{\mathrm{a}}$ & $45.9 \pm 1.0^{\mathrm{b}}$ & $41.6 \pm 1.9^{\mathrm{a}}$ & $49.7 \pm 2.0^{c}$ \\
\hline PDCAAS & $41.3 \pm 1.9^{b}$ & $37.7 \pm 2.9^{\mathrm{a}}$ & $42.3 \pm 2.8^{b}$ & $38.8 \pm 1.9^{\mathrm{a}}$ & $46.1 \pm 1.2^{\mathrm{c}}$ \\
\hline EAA & $88.3 \pm 0.9^{\mathrm{bc}}$ & $85.9 \pm 1.4^{\mathrm{a}}$ & $88.7 \pm 0.7^{\mathrm{cd}}$ & $86.3 \pm 1.6^{\mathrm{a}}$ & $90.3 \pm 0.9^{\mathrm{d}}$ \\
\hline
\end{tabular}

Values in lines with different letters $(\mathrm{a}, \mathrm{b}, \mathrm{c})$ are significantly different, $\mathrm{P} \leq 0.05$.

Table 4. Biological value of proteins and body gain in animal study

\begin{tabular}{lccccc}
\hline \multirow{2}{*}{ Treatment } & Body gain, $\mathrm{g}$ & $\mathrm{BV}, \%$ & $\mathrm{TD}, \%$ & $\mathrm{NPU}, \%$ & PER, $\%$ \\
\cline { 2 - 6 } & $\mathrm{X} \pm \mathrm{SD}$ & $\mathrm{X} \pm \mathrm{SD}$ & $\mathrm{X} \pm \mathrm{SD}$ & $\mathrm{X} \pm \mathrm{SD}$ & $\mathrm{X} \pm \mathrm{SD}$ \\
\hline Conventional WM & $21.00 \pm 0.94^{\mathrm{bc}}$ & $56.3 \pm 2.6^{\mathrm{a}}$ & $91.6 \pm 2.6^{\mathrm{a}}$ & $51.6 \pm 3.1^{\mathrm{a}}$ & $0.77 \pm 0.11^{\mathrm{ab}}$ \\
Conventional WM, sourdough & $18.33 \pm 0.83^{\mathrm{ab}}$ & $58.6 \pm 3.5^{\mathrm{a}}$ & $91.4 \pm 4.3^{\mathrm{a}}$ & $53.6 \pm 5.0^{\mathrm{a}}$ & $0.80 \pm 0.15^{\mathrm{ab}}$ \\
PBF WM & $18.00 \pm 0.78^{\mathrm{ab}}$ & $59.9 \pm 4.2^{\mathrm{a}}$ & $92.3 \pm 4.6^{\mathrm{a}}$ & $55.4 \pm 5.8^{\mathrm{a}}$ & $0.67 \pm 0.10^{\mathrm{a}}$ \\
PBF WM sourdough & $14.00 \pm 0.64^{\mathrm{a}}$ & $60.2 \pm 3.3^{\mathrm{a}}$ & $93.3 \pm 1.9^{\mathrm{a}}$ & $56.2 \pm 3.4^{\mathrm{a}}$ & $0.65 \pm 0.07^{\mathrm{a}}$ \\
$\begin{array}{l}\text { PBF WM, sourdough, whey } \\
\text { proteins }\end{array}$ & $24.33 \pm 0.91^{\mathrm{c}}$ & $67.3 \pm 4.4^{\mathrm{b}}$ & $92.7 \pm 2.3^{\mathrm{a}}$ & $62.4 \pm 5.1^{\mathrm{b}}$ & $0.80 \pm 0.10^{\mathrm{b}}$ \\
\hline
\end{tabular}

Data are expressed as means $(n=6)$; values in column with different letters (a, b, c) are significantly different, $\mathrm{P} \leq 0.05$. 


\section{Minerals concentration in serum}

The concentration of calcium, phosphorus and iron in serum of rats was not affected by different types of breads used in experimental diets. The level of magnesium was significantly lower in the serum of rats fed with diet containing PBF WM bread with sourdough and whey proteins in comparison to the diet enriched with conventional WM bread with sourdough (Table 5).

\section{Content of minerals in livers and femoral bones}

Content of calcium was significantly lower in livers of rats fed with diet with PBF WM bread with sourdough and PBF WM bred with sourdough and whey proteins in comparison to the rest of experimental groups. Experimental breads did not affect the content of phosphorus in livers of rats. Rodents fed diet with PBF WM bread had significantly lower level of magnesium in liver in comparison to rodents fed with conventional WM bread. The content of iron was significantly higher in liver of rats fed with PBF WM with sourdough bread in comparison to group fed with conventional WM and conventional WM bread with sourdough. There was no effect of addition of breads to the experimental diets on levels all measured minerals in femoral bones of rodents (Table 5).

Table 5. Minerals concentration in rats fed experimental diets

\begin{tabular}{|c|c|c|c|c|}
\hline \multirow{2}{*}{ Treatment } & $\mathrm{Ca}$ & $\mathrm{P}$ & $\mathrm{Mg}$ & $\mathrm{Fe}$ \\
\hline & $\mathrm{X} \pm \mathrm{SD}$ & $\mathrm{X} \pm \mathrm{SD}$ & $\mathrm{X} \pm \mathrm{SD}$ & $\mathrm{X} \pm \mathrm{SD}$ \\
\hline \multicolumn{5}{|l|}{ Serum, $\mu \mathrm{mol} \cdot \mathrm{l}^{-1}$} \\
\hline Conventional WM & $2.79 \pm 0.02^{\mathrm{a}}$ & $2.70 \pm 0.07^{\mathrm{a}}$ & $1.52 \pm 0.03^{\mathrm{ab}}$ & $34.04 \pm 2.00^{\mathrm{a}}$ \\
\hline Conventional WM sourdough & $2.81 \pm 0.03^{\mathrm{a}}$ & $3.00 \pm 0.01^{\mathrm{a}}$ & $1.54 \pm 0.04^{\mathrm{b}}$ & $39.10 \pm 1.23^{\mathrm{a}}$ \\
\hline PBF WM & $2.71 \pm 0.01^{\mathrm{a}}$ & $2.75 \pm 0.04^{\mathrm{a}}$ & $1.47 \pm 0.02^{\mathrm{ab}}$ & $29.77 \pm 1.40^{\mathrm{a}}$ \\
\hline PBF WM sourdough & $2.78 \pm 0.01^{\mathrm{a}}$ & $2.79 \pm 0.02^{\mathrm{a}}$ & $1.36 \pm 0.02^{\mathrm{ab}}$ & $29.68 \pm 0.92^{\mathrm{a}}$ \\
\hline PBF WM, sourdough, whey proteins & $2.70 \pm 0.00^{\mathrm{a}}$ & $2.61 \pm 0.07^{\mathrm{a}}$ & $1.32 \pm 0.02^{\mathrm{a}}$ & $29.89 \pm 0.61^{\mathrm{a}}$ \\
\hline \multicolumn{5}{|l|}{ Liver, $\mathrm{mg} \cdot 100 \mathrm{~g}^{-1}$ d.m. } \\
\hline Conventional WM & $3.35 \pm 0.43^{\mathrm{a}}$ & $340.55 \pm 16.98^{\mathrm{a}}$ & $25.39 \pm 0.47^{\mathrm{b}}$ & $9.43 \pm 1.08^{\mathrm{a}}$ \\
\hline Conventional WM, sourdough & $3.10 \pm 0.40^{\mathrm{a}}$ & $337.45 \pm 9.17^{\mathrm{a}}$ & $24.75 \pm 1.13^{\mathrm{ab}}$ & $9.30 \pm 1.39^{\mathrm{a}}$ \\
\hline PBF WM & $3.36 \pm 0.22^{\mathrm{a}}$ & $332.29 \pm 17.16^{\mathrm{a}}$ & $24.65 \pm 0.95^{\mathrm{a}}$ & $10.43 \pm 1.66^{\mathrm{ab}}$ \\
\hline PBF WM sourdough & $2.65 \pm 0.17^{\mathrm{b}}$ & $328.68 \pm 8.90^{\mathrm{a}}$ & $25.47 \pm 0.49^{\mathrm{ab}}$ & $10.67 \pm 1.43^{b}$ \\
\hline PBF WM, sourdough, whey proteins & $2.46 \pm 0.19^{b}$ & $330.16 \pm 14.77^{\mathrm{a}}$ & $24.92 \pm 0.61^{\mathrm{ab}}$ & $9.56 \pm 1.26^{\mathrm{ab}}$ \\
\hline \multicolumn{5}{|l|}{ Femoral bone, $\mathrm{mg} \cdot 100 \mathrm{~g}^{-1} \mathrm{~d} . \mathrm{m}$. } \\
\hline Conventional WM & $13400 \pm 419^{\mathrm{a}}$ & $261.59 \pm 9.46^{\mathrm{a}}$ & $199.85 \pm 7.95^{\mathrm{a}}$ & $5.02 \pm 0.81^{\mathrm{a}}$ \\
\hline Conventional WM, sourdough & $13994 \pm 492^{\mathrm{a}}$ & $270.39 \pm 7.00^{\mathrm{a}}$ & $207.89 \pm 2.86^{\mathrm{a}}$ & $4.63 \pm 0.51^{\mathrm{a}}$ \\
\hline PBF WM & $13733 \pm 478^{\mathrm{a}}$ & $270.82 \pm 9.35^{\mathrm{a}}$ & $211.13 \pm 9.75^{\mathrm{a}}$ & $4.03 \pm 0.66^{\mathrm{a}}$ \\
\hline PBF WM sourdough & $13790 \pm 665^{a}$ & $274.71 \pm 15.10^{\mathrm{a}}$ & $207.36 \pm 11.11^{\mathrm{a}}$ & $5.41 \pm 0.88^{\mathrm{a}}$ \\
\hline PBF WM, sourdough, whey proteins & $13697 \pm 713^{\mathrm{a}}$ & $275.79 \pm 13.86^{\mathrm{a}}$ & $209.11 \pm 9.98^{\mathrm{a}}$ & $5.21 \pm 0.73^{\mathrm{a}}$ \\
\hline
\end{tabular}

Data are expressed as means $(n=6)$; values in column with different letters (a, b, c) are significantly different, $\mathrm{P} \leq 0.05$. 


\section{DISCUSSION}

The aim of this study was to investigate whether an addition of sourdough and whey proteins and/or bakeoff technology affected the nutritive value of breads in vivo.

An average proteins content in experimental, wholemeal wheat breads was $16.5 \%$. Technology of baking and addition of sourdough and whey proteins to experimental breads did not affect the content of proteins in all tested breads. Wholemeal wheat flour with a degree of extraction of $100 \%$ contained up to $14.2 \%$ of proteins on a dry weight [Dewettinck et al. 2008]. Lower level of proteins (12-12.5\%) in wholemeal breads reported Lappi et al. [2010].

The fat content in experimental breads was 2.17$-2.43 \mathrm{~g}$ d.m. which confirms results given by the other authors $(0.7-2.5 \%)$, also the level of carbohydrates was within the data cited by the other authors [Burton and Lightowler 2007].

The high fiber content (11.16-13.75\%) was the result of using wholemeal flour. According to the literature data, the content of dietary fiber in wholemeal bread with an addition of sourdough was in the range of 8.4-13.5\% [Rzedzicki and Kasprzak 2009].

The level of total dietary fiber was significantly lower in conventional WM bread with sourdough, and PBF WM bread with sourdough in comparison to conventional WM and PBF WM breads. It may be suggested that microorganisms added with sourdough to bread during fermentation process metabolized certain parts of fiber. It was also found that the highest content of fiber was in PBF WM bread. It may be suggested that during the freezing process resistant starch was produced and it was the reason of higher content of fiber in frozen stored bread. Siljeström et al. [1988] showed that sourdough fermentation had no effect on the level of soluble and insoluble fraction of dietary fiber in breads.

There was no difference in ash content between experimental breads. The level of ash was similar with results published by Horubałowa and Haber [1980]. Higher content of ash in bread prepared from wholemeal flour $(3.61 \%$ d.m.) were reported by Rzedzicki and Kasprzak [2009].

The value of CS for the experimental breads was in the range of $41.2-49.7 \%$. In all the breads the same basic raw material was used, i.e. wholemeal flour $100 \%$ extract. Results within this range were obtained by Kawka and Kędzior [2003] for the CS value of wheat grain $(48.62 \%)$. These values were similar, because the experimental breads were baked from the wholemeal flour of similar composition to the whole grain. These types of breads, beside the high content of fiber, also have a large amount of lysine, as compared to white flour. This is due to the presence of dark bran in the flour and germ, which contain 3.9\% and 5.4\% lysine, respectively. The endosperm, which is a basis for white flour contains only $1.9-2.6 \%$ of this amino acid. This fact is reflected in low values of the CS rate for white wheat flour $(30.5 \%)$ and white wheat bread (30\%) [Kawka and Kędzior 2003]. According to the other literature CS of various cereal products stands at $43 \%$ for plain bread and oatmeal, $36 \%$ for graham bread, 35\% for white bread [Jabłoński and Kazimierczak 2001].

Chemical score - CS of PBF WM bread with sourdough and whey proteins was significantly higher in comparison to the rest of experimental breads. Whey proteins are a rich source of essential amino acids and contain large amounts of lysine (9.95 g per $16 \mathrm{~g} \mathrm{~N})$. They may be used in production of bread in order to improve biological value of proteins [FAO/WHO 2001]. Jabłoński and Kaźmierczak [2001] reported that the combination of wholemeal bread and milk increased the CS value from $36 \%$ to $65 \%$ as compared to wholemeal bread without any additive. Such tendency was shown also in this study.

Partially baked frozen - PBF WM bread with sourdough and whey protein had highest PDCAAS value in comparison to the rest of experimental breads. Whey protein, have high nutritional value, comparable to nutritional value of egg protein (for a long time it was regarded as a model protein). In addition, whey proteins contain about $60 \%$ of essential amino acids [FAO/WHO 2001].

There was no effect of baking method on the EAA index, however an addition of whey proteins to WM bread with sourdough significantly increased this value. On the other hand conventional WM bread with sourdough and PBF bread with sourdough had significantly lower EAA index in comparison to conventional WM and PBF WM breads with sourdough and whey proteins. It may be suggested that microorganisms 
added with sourdough used some amino acids for growing and metabolism [Poutanen et al. 2009].

Rats fed diet with an addition of PBF WM bread with sourdough and whey protein had significantly higher body gain in comparison to animals fed with conventional WM sourdough, PBF WM and PBF WM with sourdough breads. Body weight gain, depends primary on the quality and amount of proteins used in experimental diets. In all experiments the sources of proteins were breads and the level of proteins in each diet was the same. It was mentioned before that those cereal products are deficient in lysine, which limits the value of proteins. Addition of whey proteins to bread improved quality of bread proteins and body gain of rats. In the literature there is a lack of data concerning the effect of breads enriched with whey proteins on rodents' body gain. Adam et al. [2002] reported that whole wheat bread had no effect on body gain of rats. Also Östman et al. [2005] showed that wheat bread with addition of lactic acid did not affect body gain of hyperinsulinaemic (fa/fa) Zucker rats.

The highest value of the PER (0.8) was obtained for animals fed diet with an addition of conventional WM and PBF WM bread with sourdough and whey proteins. Jabłoński [2000] reported that value of PER for certain plant origin foods is lower in relation to animal origin foods (1.1 for wheat, 1.2 for potato, 1.7 for beans, 2.4 for chicken and beef, 3.0 for fish meal, 3.1 for whole milk and 3.4 for the egg). Values of PER obtained in our study were much lower in comparison to data published by Gąsiorowski [2004], who reported PER value of 1.43 for wheat.

Biological value - BV of breads' proteins was in the range $56.3-67.3 \%$. Lower BV of plant proteins (including cereals), determines their low digestibility and slow release of amino acids during digestion. Moreover, the flour of $100 \%$ extract is rich in fiber, which makes it difficult for proteolytic enzymes to contact the proteins in the interior of cells. This may likely lower the BV of proteins. Leenaars and Moughan [1993] found that wheat breads of high fiber content had no effect on BV in comparison to low fiber breads. Gąsiorowski [2004] did not find any relationship between type of flour and BV index. This author reported that the flours of $66,75,87$ and $100 \%$ extract had BV of $58.9 \%, 55.9 \%, 57.3 \%$, and $61.3 \%$, respectively. Similar results also received Forsum
[1979], studying the effect of whey protein concentrate added to wheat flour. Value of BV for wheat flour on the level of $51.3 \%$, increased with increasing amount of whey added to flour. In his experiment the mixtures of flour and whey in the proportions 83:17, 50:50, and 17:83 had BV values of 68.0, 91.9 and $96.4 \%$, respectively.

Total digestibility of protein - TD value was not affected by baking technology and an addition of sourdough and whey proteins to the experimental breads. Digestibility of proteins of plant origin ranged from 60 to $85 \%$. Digestibility of proteins depended not only on their origin, but also on several other factors, such as: the chemical composition of food, fiber content, presence of inhibitors of digestive enzymes, the type of technological treatment applied during processing, the degree of granulation of the product, etc. [Dewettinck et al. 2008, Gąsiorowski 2004]. According to Gąsiorowski [2004], the protein digestibility of flour was inversely proportional to its extract. The highest digestibility author noted for flour of $75 \%$ extract $96.6 \%$, whereas for flour of $100 \%$ extract the digestibility reached $91.6 \%$. Generally, according to the literature data an addition of sourdough increased digestibility of breads [Poutanen et al. 2009, Diowksz 2005]. Acids produced during fermentation lower $\mathrm{pH}$ of dough and affected the enzymes activity. Some enzymes, especially gluten associated proteinases were active at $\mathrm{pH}$ level below 4 which might increase the content of free amino acids in breads [Katina et al. 2005]. These data were not confirmed in our study, even upon $15 \%$ addition of sourdough.

Net protein utilization - NPU value was higher for PBF WM bread with sourdough and whey proteins and lowest for conventional WM bread (Table 4). According to literature NPU value for different cereal products was $63,51,61$ and $48 \%$ for rye white flour, wheat white flour, wholemeal rye bread, and wheat bread, respectively [Gąsiorowski 2004].

An addition of different breads to the experimental diets did not affect concentration of calcium in serum and femoral bones of experimental rats (Table 5$)$. The significantly $(\mathrm{P}<0.05)$ lower content of calcium was found in livers of rodents fed with PBF bread with sourdough and PBF bread with sourdough and whey proteins. Coudray et al. [2001] reported that rats fed with whole wheat flour had significantly 
lower concentration of calcium in serum compared to rats fed diet with the addition of white wheat flour. Concentration of this mineral in tibia was not affected by different types of flours used in this study. Levrat-Verny et al. [1999] did not find effect of calcium content in serum, liver, and tibia of rats fed with whole wheat flours.

Any type of bread caused a significant effect on the concentration of phosphorus in the serum, liver and femoral bone of experimental animals. All experimental breads had high content of this mineral. Whole wheat bread contained high amounts of phosphorus, but it occurred mainly in phytic acid. An addition of sourdough decreased $\mathrm{pH}$ of the dough and increased both the activity of phytase and the level of inorganic phosphate [Poutanen et al. 2009, Lopez et al. 2003].

The highest magnesium content was determined in the serum of rodents fed the diet containing conventional WM bread with sourdough as compared to rats fed diet with PBF WM bread with sourdough and whey proteins. It was reported that an addition of sourdough increased magnesium solubility and absorption of these mineral in animal model [Lopez et al. 2003]. Levrat-Verny et al. [1999] also showed higher content of magnesium in plasma, and tibia of rats fed diet with whole wheat flour as compared to animals fed diet with white flour. Coudray et al. [2001] reported that rats fed diet with whole flour had significantly higher level of magnesium in serum and tibia as compared to rats fed diet with white flour.

Concentration of iron in the serum and femoral bone of rodents was affected neither by baking technology, nor by the addition of sourdough or whey proteins (Table 5). Animals fed diet enriched with PBF WM bread with sourdough had significantly higher concentration of iron in the liver as compared to rats fed with conventional WM, and conventional WM bread with sourdough. PBF bread with sourdough was not the richest source of iron. It may be suggested that, the acidification during fermentation of dough increased the solubility of this component and thereby improved its bioavailability. Our results are confirmed by Chaoui et al. [2000]. These authors found that mice fed bread enriched with sourdough, and iron had higher iron content of ferritin, hemoglobin and hematocrit in serum, while reduced level of iron excreted in the faeces. Levrat-Verny et al. [1999] reported that feeding rats with whole wheat flour increased content of iron in plasma, liver and tibia. Similar results were reported also by Courday et al. [2001]. We did not find an effect of wholemeal bread on concentration of iron in animals.

\section{CONCLUSIONS}

Bake-off technology did not affect nutritional value of experimental breads prepared from wholemeal flour. An addition of sourdough and whey proteins to the PBF WM bread improved quality of proteins (BV and NPU were increased), which is an important finding because usually bread's proteins have low quality. On the other hand an addition of sourdough and whey proteins decreased the level of magnesium in serum of experimental animals. It can be suggested that sourdough addition can be recommended in the production of whole wheat partially baked frozen bread while its use is further more beneficial when fermented with whey proteins.

\section{SUMMARY}

Opportunity to obtain a finished product by using bake-off technology in a store or home conditions is convenient, while providing bread with good nutritional value. The use of whole grain flour and various functional additives (sourdough, whey proteins) incorporated into such breads, is completely possible and allows obtaining a valuable product in terms of nutrition and pro-health properties. Sourdough addition can be recommended in a production of whole wheat partially baked frozen bread but its use is further more beneficial when fermented with whey proteins.

\section{ACKNOWLEDGEMENT}

This study has been carried out with financial support from the Commission of the European Communities, FP6, Thematic Area "Food quality and safety FOOD 2006 - 36302 - EU-FRESH BAKE". It does not necessarily reflect its views and in no way anticipates the Commission's future policy in this area. This study was supported also by the Polish Ministry of Science and Higher Education, grant 162/6 PR $\mathrm{EU} / 2007 / 7$. 


\section{REFERENCES}

AOAC, 2006. Official Methods of Analysis. Association of Official Analytical Chemists International Gaintersburg.

Adam A., Lopez H.W., Tressol J.-C., Leuillet M., Demigné C., Rémésy C., 2002. Impact of whole wheat flour and its milling fractions on the cecal fermentations and the plasma and liver lipids rats. J. Agric. Food Chem. 50 (22), 6557-6562.

Burton P., Lightowler H.J., 2007. The impact of freezing and toasting on the glycaemic response of white bread. Eur. J. Clin. Nutr. 62 (5), 594-599.

Courday C., Levrat-Verny M., Tressol J.C., Feillet-Coudray C., Horcajada-Molterini N.M., Demigné C., Rayssiguier Y., Rémésy C., 2001. Mineral supplementation of white wheat flours is necessary to maintain adequate mineral status and bone characteristics in rats. J. Trace Elem. Med. Biol. 15 (2-3), 131-137.

Chaoui A., Faid M., Belahsen R., 2006. Making bread with sourdough improves iron bioavailability from reconstituted fortified wheat flour in mice. J. Trace Elem. Med. Biol. 20 (4), 217-220.

Davidson I., 2003. Hydrolysis of samples for amino acid analysis. In: Methods in molecular biology 211. Protein Sequencing protocols. Ed. B.J. Smith. Humana Press Totowa, New Jersey, 111-122.

Dewettinck K., Van Bockstaele F., Kühne B., Van de Walle D., Courtens T.M., Gellynck X., 2008. Nutritional value of bread: Influence of processing, food interaction and consumer perception. J. Cereal Sci. 48 (20), 243-257.

Diowksz A., 2005. Rola kultur starterowych w nowoczesnym piekarstwie [The role of starter culture in modern baking]. Cukiern. Piekar. 6, 32-35 [in Polish].

EN-13804, 2002. Food products. Determination of trace elements. Criteria [in Polish].

EN-13805, 2003. Food products determination of trace elements. Pressure mineralization [in Polish].

EN-14084, 2003. Food products. Determination of trace elements. Determination of $\mathrm{Pb}, \mathrm{Cd}, \mathrm{Zn}, \mathrm{Cu}$, and $\mathrm{Fe}$ content by the use of atomic absorption spectroscopy (AAS) after microwave mineralization [in Polish].

FAO/WHO, 2001. Protein quality evaluation. Report of a Joint FAO/WHO Expert Consultation. Food and Nutrition. FAO Roma.

FAO/WHO, 2007. Protein and amino acid requirements in human nutrition Report of a joint FAO/WHO/UNU Expert Consultation Geneva.

Gawęcki J., 2010. Żywienie człowieka. Podstawy nauki o żywieniu [Human nutrition. Basic of science nutrition]. PWN Warszawa [in Polish].
Górecka D., Pachołek B., Dziedzic K., Górecka M., 2010. Raspberry pomace as a potential fiber source for cookies enrichment. Acta Sci. Pol., Technol. Aliment. 9 (4), 451-462.

Forsum E., 1979. Biological evaluation of wheat supplemented by a whey protein concentrate or whey cheese on growing rats. J. Dairy Sci. 62 (8), 1207-1210.

Gąsiorowski H., 2004. Pszenica - chemia i technologia [Wheat - chemistry and technology]. PWRiL Poznań [in Polish].

Horubałowa A., Haber T., 1980. Analiza techniczna w piekarstwie [Technical analysis in bakery]. WSiP Warszawa [in Polish].

Jabłoński E., Kaźmierczak U., 2001. Wartość odżywcza dań i przetworów zawierających białko mleka [Nutritional value of meals and products containing milk proteins]. Przegl. Mlecz. 7, 290-293 [in Polish].

Katina K., Arendt E., Liukkonen K.-H., Autio K., Flander L., Poutanen K., 2005. Potential of sourdough for healthier cereal products. Trends Food. Sci. Technol. 16 (1-3), 104-112.

Kawka A., Kędzior Z., 2003. Proteins from plant origin food, characteristics and nutrional value. In: Białka w żywności i żywieniu. Ed. J. Gawęcki. Wyd. AR Poznań, $42-57$ [in Polish].

Kopeć A., Pysz M., Borczak B., Sikora E., Rossel C.M., Collar C., Sikora M., 2011. Effects of sourdough and dietary fibers on the nutritional quality of breads produced by bake-off technology. J. Cereal Sci. 54 (3), 499-505.

Lappi J., Selinheimo E., Schwab U., Katina K., Lehtinen P., Mykkänen H., Kolehmainen M., Poutanen K., 2010. Sourdough fermentation of wholemeal wheat bread increases solubility of arabinoxylan and protein and decreases postprandial glucose and insulin response. J. Cereal Sci. 51 (1), 152-158.

Levrat-Verny M., Courday C., Bellanger J., Lopez H.W., Demigné C.M.A., Rayssiguier Y., Rémésy C., 1999. Whole wheat flour ensures higher mineral absorbtion and bioavailability than white wheat flour in rats. Br. J. Nutr. 82 (1), 17-21.

Leenaars M., Moughan P.J., 1993. The apparent digestibility of energy, nitrogen and fibre and the biological value of protein in low and high-fibre wheat breads. Plant Foods Hum. Nutr. 44 (2), 187-194.

Lopez H.W., Duclos V., Coudray C., Krespine V., FeilletCoudr C., Messager A., Demigné C., Rémésy C., 2003. Making bread with sourdough improves mineral bioavailbility from reconstructed whole wheat flour in rats. Nutrition 19 (6), 524-530. 
Kopeć A., Borczak B., Pysz M., Sikora E., Sikora M., Curic D., Novotni D., 2014. An addition of sourdough and whey proteins affects the nutritional quality of wholemeal wheat bread. Acta Sci. Pol., Technol. Aliment. 13(1), 43-54.

Novotni D., Ćurić D., Bituh M., Barić I.C., Škevin D., Čukelj N., 2011. Glycemic index and phenolics of partially-baked frozen bread with sourdough. Int. J. Food Sci. Nutr. 62 (1), 26-33.

Östman E.M., Elmstahl H., Molin G., Lundquist I., Bjorck I., 2005. A diet based on wheat bread baked with lactic acid improves glucose tolerance in hyperinsulinaemic Zucker $(f a / f a)$ rats. J. Cereal Sci. 42 (3), 300-308.

Poutanen K., Flander L., Katina K., 2009. Sourdough and cereal fermentation in nutritional perspective. Food Microbiol. 26 (7), 693-699.

Pysz-Izdebska K., Leszczyńska T., Kopeć A., Nowacka E., Bugaj B., 2010. Pokrycie zapotrzebowania na energie i wybrane składniki odżywcze w diecie pensjonariuszy Domu Pomocy Społecznej oraz ocena ich parametrów antropometrycznych [Meeting the demand for energy and selected nutrients in diets of residents of one selected residential care home for adults and evaluation of their anthropometric parameters]. Żywn. Nauka Techn. Jakość 6 (73), 239-254 [in Polish].

Reeves P.G., Nielsen F.H., Fahey G.C., 1993. AIN-93 purified diets for laboratory rodents: final report of the
American Institute of Nutrition ad hoc writing committee on the reformulation of the AIN-76A rodent diet. J. Nutr. 123 (11), 1939-1951.

Rosell C.M., Santos E., Sanz-Penella J.M., Haros M., 2009. Wholemeal wheat bread: a comparison of different breadmaking processes and fungal phytase. J. Cereal Sci. 50 (2), 272-277.

Rzedzicki Z., Kasprzak M., 2009. Badania składu chemicznego wybranych sortymentów pieczywa ciemnego [Study of chemical composition selected assortments of bread]. Bromat. Chem. Toksykol. 3, 277-281 [in Polish].

Siljeström M., Björck I., Eliasson A.-C., Lönner C., Nyman M., Asp N.-G., 1988. Effect of polisacharidies during baking and storage of bread - in vitro and in vivo studies. Cereal Chem. 65, 1-8.

WHO/FAO, 2003. Report on Joint WHO/FAO Expert Consultation. Diet, Nutrition and the Prevention of Chronic Diseases Geneva.

Winiarska-Mieczan A., Kwiecień M., 2011. Evaluation of the mineral composition of breadstuff and frequency its consumption. Acta Sci. Pol., Technol. Aliment. 10 (4), 487-495.

\section{WPLYW DODATKU ZAKWASU I BIAŁEK SERWATKOWYCH NA WARTOŚĆ ODŻYWCZĄ PIECZYWA Z PEENEGO PRZEMIAtU}

\section{STRESZCZENIE}

Wstęp. Chleb jest cennym źródłem odżywczych oraz nieodżywczych składników w diecie. W pracy oceniono dodatek zakwasu i białek serwatkowych do pieczywa pełnoziarnistego, wypiekanego metodą odroczonego wypieku (PBF WM), na skład chemiczny oraz biodostępność białek, wapnia, magnezu i żelaza w organizmach szczurów doświadczalnych szczepu Wistar.

Materiał i metody. Pieczywo z pełnego przemiału (WM) wypiekano metodą wypieku tradycyjnego bądź odroczonego. W tak przygotowanym materiale oznaczono skład podstawowy, zawartość wybranych składników odżywczych i zawartość aminokwasów. Doświadczenie żywieniowe przeprowadzono z udziałem pięciotygodniowych samców szczurów Wistar $(n=30)$. Zwierzęta podzielono na pięć grup i karmiono dietami doświadczalnymi $\mathrm{z}$ dodatkiem chlebów eksperymentalnych. W doświadczeniu oceniano wartość biologiczną białek chleba oraz zawartość wybranych składników mineralnych w surowicy, wątrobie i kościach udowych szczurów.

Wyniki. Chleb pełnoziarnisty, wypiekany metodą odroczonego wypieku, z dodatkiem zakwasu i białek serwatkowych istotnie zwiększył przyrosty masy ciała, wartość biologiczną (BV) oraz wykorzystanie białka netto (NPU) w organizmach szczurów doświadczalnych. Poziom magnezu był istotnie niższy w surowicy krwi szczurów karmionych chlebem pełnoziarnistym, wypiekanym metodą odroczonego wypieku, z dodatkiem zakwasu i białek serwatkowych, w porównaniu z ilością tego składnika w surowicy krwi szczurów żywionych chlebem pełnoziarnistym, wypiekanym metodą tradycyjną z dodatkiem zakwasu. Zawartość żelaza istotnie wzrosła w wątrobach szczurów karmionych chlebem pełnoziarnistym PBF WM z dodatkiem zakwasu, w porównaniu ze szczurami karmionymi chlebem pełnoziarnistym wypiekanym metodą tradycyjną bez oraz z dodatkiem zakwasu. 
Kopeć A., Borczak B., Pysz M., Sikora E., Sikora M., Curic D., Novotni D., 2014. An addition of sourdough and whey proteins affects the nutritional quality of wholemeal wheat bread. Acta Sci. Pol., Technol. Aliment. 13(1), 43-54.

Wnioski. Dodatek zakwasu wpływa korzystnie na wartość odżywczą pieczywa pełnoziarnistego wypiekanego metodą odroczonego wypieku, zwłaszcza w obecności białek serwatkowych.

Słowa kluczowe: składniki mineralne, metoda odroczonego wypieku, zakwas, białka serwatkowe, pieczywo z pełnego przemiału, szczury

For citation - Do cytowania

Kopeć A., Borczak B., Pysz M., Sikora E., Sikora M., Curic D., Novotni D., 2014. An addition of sourdough and whey proteins affects the nutritional quality of wholemeal wheat bread. Acta Sci. Pol., Technol. Aliment. 13(1), 43-54. 